\author{
Nikolai Fateev \\ Candidate of Technical Sciences, Professor \\ Admiral Makarov National University of Shipbuilding, Mykolaiv, Ukraine \\ E-mail: nikolay.fateev@nuos.edu.ua \\ ORCID: https://orcid.org/0000-0002-2663-6440 \\ Iryna Zaporozhets \\ Candidate of Technical Sciences, Associate Professor \\ Admiral Makarov National University of Shipbuilding, Mykolaiv, Ukraine \\ E-mail: iryna.zaporozhets@nuos.edu.ua \\ ORCID: https://orcid.org/0000-0003-4015-5958 \\ ResearcherID: U-4239-2017
}

\title{
Mechanisms of operational portfolio management of projects in shipbuilding and ship repair
}

\begin{abstract}
Over the past decades, the competitiveness of enterprises in the world shipbuilding and ship repair markets is being determined by the level of development of information and communication technologies, on the basis of which global value chains are being formed. The shipbuilding 4.0 methodology is being introduced in the industry, which is based on the advanced technologies of the fourth industrial revolution. The aim of the article is to study the models and mechanisms for portfolio management of shipbuilding and ship repair enterprises on the basis of modern information technology for the effective implementation of strategic goals and sustainable development. The basis of the organizational and methodological support of portfolio management of shipbuilding enterprises is a system of planning and accounting units. This is a three-level model for the shipbuilding work breakdown. The first level of work breakdown consists of shop stages (list of works performed by a certain production department). The second level of work breakdown is technological sets that are being formed in the process of production planning on the principles of structural and technological unity of work and are the basic elements in the intershop operational management. Technological operations are carried out at the third level of work breakdown (brigade sets). At the upper levels of shipbuilding work breakdown, all the key features of project management take place. Technological sets are recommended to be used as an information and analytical basis when developing the network models at the upper levels of structural work breakdown. The methodology for portfolio management of projects of a shipbuilding enterprise described in the article is aimed at aligning the goals and objectives of individual projects and the portfolio as a whole with the strategic plans of the enterprise.
\end{abstract}

\author{
Keywords \\ Work breakdown, project \\ network model, information \\ technology, project \\ management, technological \\ sets, project resources.
}

JEL: M11, M15, O22

DOI: https://doi.org/10.30525/2500-946X/2021-1-9

\section{Introduction}

Business process management in modern companies is based on information technology. Information flows bring together supply chain participants, different functions and tasks of supply chain management. For effective information management, corporate information systems are being developed and implemented. The structure of such systems and the vector of their development should be implemented in accordance with the strategy of the enterprise's competitive behavior.

In the leading countries of the global shipbuilding market, the shipbuilding 4.0 methodology is being introduced, which is based on the advanced technologies of the fourth industrial revolution. The shipbuilding 4.0 methodology has clear goals of reducing the expenses and duration of shipbuilding, improving the quality of the final product in order to achieve sustainable competitiveness.

Shipbuilding and ship repair are complex organizational and technical systems that have a project-oriented nature of production and, as a result, a clearly expressed matrix organizational structure (combination of functional and project management). At the same time, shipbuilding and ship repair are characterized by a strong matrix, where the characteristics of project management prevail, project managers have broad powers.

In these conditions, in the management system of shipbuilding and ship repair enterprises, it is necessary to implement the concept of project management using modern information technology, which determines the relevance of the topic and content of the article.

Analysis of recent research and publications. Project management is a section of modern management theory. But at the beginning of the 50s of the twentieth century, models of network scheduling and management were developed, using methods of graph theory to build and optimize network diagrams of projects and resource allocation. In the 70s of the twentieth century, procedures were formed based on the development and analysis of mathematical models of organizational project management. At the same time, project management information systems are being developed, this allows to obtain, store and use information 
about projects and their environment for decisionmaking. To date, there are a significant number of project management software of various scales.

Standardization in project management has become a necessary attribute. Industry and national standards are being developed. The influential standard is PMBOK - the US national standard (PMBOK Guide, 2017: 976). The world's leading organization for ISO standardization has developed its own project management standard (International standard ISO 21500, 2012), which is the unifying basis for project management standards at the national and corporate levels.

Fundamental research of project management models with practical recommendations are carried out under the guidance of Burkova V. M. at the V. A. Trapeznikov Institute of Management Prob-lems of the Russian Academy of Sciences (Barkalov, 2019: 189). The Ukrainian Association of Project Management under the leadership of Professor Bushuiev S. D. effectively coordinates research on project management issues, implements certification programs for project managers.

The project portfolios of shipbuilding and ship repair enterprises have a number of features (a high degree of uncertainty in the planning and implementation of projects, a long cycle of ship construction, complex supply chains in logistics processes, etc.), which significantly affect the models and mechanisms of project management. At the same time, the existing standards of project management at all levels and published research do not provide informed recommendations for the formation of procedures for effective integration of project management processes of programs and portfolios in shipbuilding and ship repair.

The aim of the article is to study the mechanisms of introduction and effective operation of the project portfolio management subsystem at shipbuilding and ship repair enterprises for the implementation of their strategic goals.

\section{Shipbuilding work breakdown}

The process of creating new ships is a complex interaction between project organizations, shipbuilding enterprises, customers, supervisory organizations, contractors. This intersection of interests creates problematic situations of different types that need to be addressed to preserve the integrity of the logistics chain of shipbuilding processes. At the same time, the management of shipbuilding and ship repair enterprises must have access to all the information necessary to make and implement informed management decisions.

In shipbuilding, planning and accounting units (PAU) are used in the design, planning and accounting of work progress. The PAU system is developed on the basis of the principle technology and organization of ship construction and includes the following elements:

- ship (order);

- shop-stages;

- technological sets (TS);

- brigade sets (BS).

Shop-stages constitute the first level of work breakdown of the shipbuilding processes included in the company's order portfolio. Shop-stages include a list of works of the project $P_{i}$ $(i=1, m)$, where $m$ is the number of projects in the portfolio performed by the shop (department) $D_{j}(j=1, n)$, where $n$ is the number of production and functional departments of the enterprise. The second level of work breakdown consists of technological sets $T_{i j g}(g=1, \mathrm{k})$, where $k$ is the number of technological sets of the project $P_{i}$ performed by the department $D_{i}$.

The technological sets are being formed in the process of production planning on the principles of constructive and technological unity of works and are the basic elements in the inter-shop operational management. The use of the scheme of technological sets creates opportunities to control production processes at the level that allows you to make and implement effective management decisions.

The third level of work breakdown consists of brigade sets $B_{i j g f}(f=1, p)$, where $\mathrm{p}$ is the number of production brigades in the structure of the department $D_{j}$. At the level of the brigade sets, technological operations are carried out, in the conditions of subject specialization and standardization of shipbuilding production, it provides for the repeatability and regularity of achieving the result (typical technological pro-cesses for manufacturing parts, sections, assem-bling and welding the hull on the slipway, modular methods of equipment installation, etc.). These characteristics determine the advisability of using the process approach in management at this level.

At the upper levels of shipbuilding work breakdown, all the features of project management take place:

- the duration of the construction of the vessel is limited with the moments of the beginning and completion of the project determined by the contract;

- limited resources required to complete work packages;

- the results of the previous stages can cause changes not only in the schedule, but also in the content of subsequent works.

\section{Project portfolio management}

To ensure sustainable development, shipbuilding enterprises in modern conditions include in the portfolio of projects, in addition to the construction of ships, contracts for the repair and modernization of ships, the manufacture of metal structures for various purposes. As a rule, portfolio projects are technologically independent but they are implemented in conditions of limited total resources of the enterprise.

Portfolio management mechanisms should ensure the implementation of portfolio projects with parameters consistent with the strategic goals of the enterprise.

The main tasks of the operational management for project portfolios are:

- completion of projects within the contractual deadlines;

- ensuring the receipt of financial resources in the planned volumes and on time;

- control over the expenses of financial resources for each project and the portfolio as a whole within the approved budgets;

- quality control at all stages of project implementation as an important factor in the competitiveness of the enterprise.

The solution of these tasks is possible only at constant monitoring and predicting of the parameters of projects in the process of their implementation and the adoption of justified management decisions based on these predictions. In the operational management of project portfolios, it is necessary to constantly compare the planned and projection indicators of the portfolio, obtained taking into account the dynamics of its actual implementation. 
Planning the implementation of individual projects is based on network diagrams of different levels of work breakdown. The network diagram is a dynamic model that includes constructive and technological preparation of production, material and technical support, production processes, quality control procedures. Network diagrams establish the sequence of work (work packages), coordinate them over time, taking into account the availability of resources.

The network diagram system can be represented in three levels. The first level is the general diagram, which formed on the basis of the parameters of contractual obligations and fundamental technology and reflects the key processes and control points (milestones) of the project. The second level is the activity network diagram that includes the interconnection of technological sets, and also sets the deadlines for the preparation of technological documentation. At the third level, the tasks of technological sets are detailed in local diagrams: manufacturing of parts and sections, installation of specific equipment, etc. The diagrams of all levels unite common control points.

Thus, the matrix of responsibility of the project portfolio for the second level of work breakdown can be represented as:

$$
\mathrm{M} \rightarrow\left\{P_{i}, D_{j}, T_{i j g}, A_{i j g}, S_{i j g}, t_{i j g}, d_{i j g}\right\},
$$

where $A_{i j g}$ is a labor-intensive work of the set,

$S_{i j g}$ is a cost of materials and components,

$t_{i j g}$ is a start date of work on the set,

$d_{i j g}$ is the duration of works on the set.

The volume of labor resources required by the $j$-th production department to implement the work of the project portfolio during the planning period $\left(t_{1}, t_{2}\right)$ can be represented as:

$$
R_{j}^{*}\left(t_{1}, t_{2}\right)=\sum_{i=1}^{m} \sum_{g=1}^{k} A_{i j g}\left(t_{1}, t_{2}\right)
$$

The volume of labor resources $R_{j}\left(t_{1}, t_{2}\right)$ that is assigned to the $j$-th production department in the planning period $\left(t_{1}, t_{2}\right)$ is a fixed value and should be distributed among the portfolio projects. In the process of implementing the portfolio, it is necessary to monitor the implementation of inequality $R_{j}^{*}\left(t_{1}, t_{2}\right) \leq R_{j}\left(t_{1}, t_{2}\right)$ as a necessary condition for successful achievement of strategic goals of the enterprise.

The parameters of the information matrix (1) $A_{i j g}$ and $S_{i j g}$ provide an opportunity to form an integral function of expenses for each project $C_{i}(t)$. To plan the revenue side of the budge $B_{i}(t)$, it is advisable to use the balance model, which allows to solve the following tasks:

- predicting the movement of financial resources for the project;

- analysis of the feasibility of borrowing funds;

- monitoring and adjusting the financial plan of the project taking into account its actual implementation.

In general, the balance model is presented as a functional: $F_{i}(t)=B_{i}(t)-C_{i}(t)$,

The positive value of the functionality $F_{i}(t)$ in terms of project implementation is a prerequisite for its successful completion. In (Matveev, 2005: 206), a centralized model of resource allocation between portfolio projects is proposed and substantiated, which ensures the coordination of the interests of project managers, heads of functional units and meets the strategic goals of a shipbuilding enterprise.

\section{Operational project management tools: budgets, project office, balanced scorecard}

An integral element of the project portfolio management mechanisms is the budget system (Fateev, 2013: 131). The significant duration of the construction and repair of ships, as well as a high degree of uncertainty, determine the need to maintain three interrelated budgets.

1. Basic project budgets are compiled at the stage of planning income and expenditure for each project. After agreement with the customer, the basic project budgets become the benchmark against which the actual results are compared at all stages of the project.

2. Current project budgets reflect the results of regulatory measures (record all changes in planned parameters).

3. Actual project budgets are formed upon completion of works and the final document at the end of the project.

The responsibility matrix (1) provides information support for these budgets, as well as budgets for the centers of financial responsibility: production departments, functional management departments, budgets for innovative development of the enterprise.

Based on the parameters of the matrix (1), a list of material and technical resources necessary for the implementation of a portfolio of projects is formed: materials, components, etc. This list, linked to the time axis, makes it possible to build algorithms for optimal use of material and technical resources.

Thus, project portfolio management focuses on the analysis of individual projects and the portfolio as a whole to establish priorities in the allocation of limited resources of the enterprise. An important element in the project portfolio management system of a shipbuilding enterprise is the project management office - an organizational structure that standardizes project management processes at the enterprise, provides communication between functional units and project managers, and controls the allocation of resources for projects. In work (Fateev, 2020: 48), based on the analysis of the features of ship repair production, the structure, functions, composition of tools and stages of the formation of a project management office are determined. The organizational structure of the project office is individual for each enterprise. The nomenclature of management tasks to be solved in the office, related to the level of maturity of general management and the project management system at the enterprise.

To ensure effective project portfolio management at the enterprise, certain prerequisites must be formed: a formalized system of strategic goals, a substantiated nomenclature of criteria for evaluating projects for compliance with a strategy, and a culture of managerial decision-making has been formed.

To assess the effectiveness of project management and its compliance with the corporate strategy, it is advisable to use a balanced scorecard (BSC). The BSC system makes it possible to assess the work of the enterprise on the basis of four balanced parameters: finance, customer relations, internal business processes, as well as training and advanced training of personnel.

\section{Conclusion}

1. Complex and highly uncertain production of shipbuilding orders is impossible without the use of project management methodology and specialized project 
management software. This will allow: improving the quality and efficiency of decision-making on planning, control and implementation of management influences; creating a single information space that will ensure the effective distribution of management information in the process of preparing and implementing projects; establishing coordination of the work of functional departments.

2. The proposed structure of the information matrix will allow to link the logical-temporal structure of projects and organizational structure of project management of the shipbuilding enterprise into a single comprehensive tool. The information model of the project allows monitoring the determination of the costs required to the implementation of the functions of each department on the project and using this information in the decision-making process. The balanced scorecard, supported by special software, provides a link between strategic goals and operational management.

3. For the effective integration of the project management system into the corporate information system of a shipbuilding enterprise, it is necessary to develop an end-to-end method for coding equipment, materials and work breakdown structure.

4. Methods and models of project management, which are implemented in matrix organizational structures, have become widespread in shipbuilding and ship repair production. Project managers have broad powers in project management, up to $60 \%$ of all organizational resources of the enterprise are involved in the project. For the sustainable development of project management methodology in shipbuilding and ship repair, it is urgent need to develop industry standards of project management.

\section{References}

[1] Fateev, N. V., \& Zaporozhets, I. M. (2020). Organization of the project management office of ship repair enterprise. Three Seas Economic Journal, 1(2), 48-52. DOI: https://doi.org/10.30525/2661-5150/2020-2-8

[2] A Guide to the Project Management Body of Knowlend (PMBOK Guide) (2017). Sixth Edition. USA, ANSI/PMI. Available at: http//www.pmi.org

[3] Mezhdunarodnyi standart ISO 21500:2012 [International standard ISO 21500:2012]. "Guidance on project management".

[4] Fateev, N. V., Zaporozhets, I. M., \& Antykova, I. V. (2013). Organizatsiya byudzhetnogo upravleniya v proektakh postroyki i remonta transportnykh sudov [Organization of budget management in projects of construction and repair of transport vessels]. Vostochno-Evropeiskiy zhurnal peredovykh tekhnologiy, 1/10 (61), 131-133. (in Russian)

[5] Barkalov, S. A., Burkov, V. N., Geldrud, Ya. D., \& Gollay, A. V. (2019). Umnoe upravleniye proektami [Smart project management]. Chelyabinsk: YuURGU. (in Russian)

[6] Matveev, A. A., Novikov, D. A., \& Tsvetkov, A. V. (2005). Modeli i metody upravleniya portfelyami proektov [Models and methods of project portfolio management]. Moscow: PMSOFT. (in Russian) 